Submitted on May 15, 2020.

\title{
Model experiment for cleaning oil-contaminated soils
}

\author{
(C) Alibek A. Kaziev, ${ }^{1 *+}$ Amantay Sh. Akzhigitov, ${ }^{2}$ \\ Sofia Z. Sagyndykova, ${ }^{3}$ and Azamat N. Nurlybekov ${ }^{3}$ \\ ${ }^{1}$ Department of Applied Biology and Microbiology. Astrakhan State Technical University. Tatishchev St. 16. \\ Astrakhan,414056.Russia.Phone:+7 (8512)614-271.E-mail: alibek.kaziev.88@mail.ru \\ ${ }^{2}$ Atyrau State University of Oil and Gas Named after Safi Utebaev. Atyrau. \\ Republic of Kazakhstan.E-mail: aman.aing@rambler.ru \\ ${ }^{3}$ Atyrau State University Named after Khalel Dosmukhamedov. Atyrau. \\ Republic of Kazakhstan.E-mail: sofiazul@mail.ru
}

\begin{abstract}
${ }^{*}$ Leading directions; ${ }^{+}$Corresponding author
Keywords: immobilization, polymerase chain reaction, nutrient medium Voroshilova-Dianova, meat peptone agar, hydrocarbon-oxidizing microorganisms, zeolite, expanded clay.
\end{abstract}

Abstract
The ability to absorb oil hydrocarbons is inherent in microorganisms represented by various systematic groups. These include various types of micromycetes, yeast, and bacteria. The most active oil destructors are found among bacteria. They are characterized by the ability to absorb a wide range of hydrocarbons, including aromatic ones, have a high growth rate and, therefore, are of great practical interest. The restoration of oilcontaminated lands is currently one of the complex and at the same time little-studied object of reclamation. The article presents the results of studies of the adsorption capacity of hydrocarbon-oxidizing microorganisms of the genera Bacillus, Micrococcus and Rhodococcus and their oil-oxidizing activity after immobilization on zeolite and expanded clay in model conditions.

It was noted that as a result of research work, strains of the microorganisms Rhodococcus, Micrococcus are better adsorbed on the surface of zeolite, expanded clay and at the same time have a high oil-oxidizing activity. Representatives of natural hydrocarbon-oxidizing microorganisms are characterized by high emulsification rates; the cultures of Rhodococcus erythropolis and Rhodococcus ruber have the highest emulsifying activity. This may indicate a high destructive activity of microorganisms. When assessing the degree of oil destruction after 60 days when introducing free cultures of microorganisms, it ranged from 32.84 to $64.94 \%$, and in the variants with the introduction of immobilized cultures of microorganisms on zeolite, oil utilization was from 47.94 to $86.84 \%$. When immobilized cells of hydrocarbon-oxidizing microorganisms were introduced onto expanded clay, the destruction ranged from 47.69 to $92.75 \%$.

\section{References}

[1] S.B. Petrikevich, E.N. Kobzev, A.N. Shkidchenko. Assessment of hydrocarbon-oxidizing activity of microorganisms. Applied Biochemistry and Microbiology. 2003. Vol.39. No.1. P.25-30. (russian)

[2] E.V. Stabnikova, M.V. Selezneva, O.N. Reva, V.N. Ivanov. The choice of an active microorganism-degrader of hydrocarbons for the purification of oil-contaminated soils. Applied Biochemistry and Microbiology. 1995. Vol.31. No.5. P.534-539. (russian)

[3] N.M. Ismailov. Microbiological and enzymatic activity of oil-contaminated soils. Recovery of oilcontaminated soil ecosystems. Moscow. 1988. P.42-56. (russian)

[4] A.P. Sinitsyn, E.I. Rainina, V.I. Lozinsky and others. Immobilized cells of microorganisms. Moscow: Publishing house of Moscow State University. 1994. P.288. (russian)

[5] Yu.E. Demidova. Immobilization of cells of microorganisms. Moscow: Scientific and technical collection. 2001. No.35. P.112-115. (russian)

[6] G.A. Kovalenko, E.V. Kuznetsova, V.M. Lenskaya. Carbon-mineraline carriers for adsorption immobilization of non-growing bacterial cells. Biotechnology. 1998. No.1. P.47-56. (russian)

[7] E.Z. Tepper and others. Ed. V.K. Shilnikova. Workshop on Microbiology: Textbook manual for universities 5th ed., revised. and add. Moscow: Dropha. 2004. P.256. (russian)

[8] B. Glick, D. Pasternak. Molecular biotechnology. Principles and application. Per. from English Moscow: World. 2002. P.589. (russian)

[9] G.L. Seliber other. Great workshop on microbiology. M oscow: Higher school. 1962. P.491. (russian) 
[10] J. Holeta. The determinant of the bacteria Bergee. Per. from English: B 2 t. M oscow: World. 1997. P.432. (russian)

[11] L.V. Lysak, T.G. Dobrovolskaya, I.N. Skvortsova. Methods for assessing the bacterial diversity of soils and the identification of soil bacteria. Moscow: MAX Press. 2003. P.120. (russian)

[12] A.V. Chemeris, E.D. Akhunov, V.A. Vakhitov. DNA sequencing. Moscow: Science. 1999. P.427. (russian)

[13] E. Gaal, G. Medieshi, L. Vereckey. Electrophoresis in the separation of biological macromolecules. Moscow: World. 1982. P.446. (russian)

[14] A.V. Mamitko, V.R. Mamitko, Z.I. Nikitina. Using the method of two-layer soil agar to assess anthropogenic disturbances of terrestrial ecosystems according to microbiological tests. Geography and natural resources. 1983. No.4. P.137-142. (russian)

[15] P.A. Kozhevin. Soil health as a biotechnology issue. 4th Mosk. Int. Congress "Biotechnology: State and Development Prospects", March 12-16, 2007. Moscow. 2007. P.114-116. (russian)

[16] T.P. Serikov, R.R. Sagyndykova, V.M. Yugay, A.B. Eskuzhieva. On environmental protection in the conditions of oil and gas production at the enterprises of Kazakhoil-Emba OAO. Oil and gas. 2001. No.1. P.83-87. (russian)

[17] Z.I. Nikitina. Microbiological monitoring of terrestrial ecosystems. Novosibirsk: Science. 1991. P.228. (russian) 